\title{
Regulation of the mannose 6-phosphate/IGF II receptor expression at the cell surface by mannose 6-phosphate, insulin like growth factors and epidermal growth factor
}

\author{
Thomas Braulke, Stefanie Tippmer, Erwin \\ Neher $^{1}$ and Kurt von Figura
}

Georg-August-Universität Göttingen, Abt. Biochemie II, Gosslerstrasse 12d, D-3400 Göttingen, and 'Max-Planck-Institut für Biophysikalische Chemie, Am Fassberg, D-3400 Göttingen, FRG

Communicated by B. Dobberstein

Mannose 6-phosphate, insulin like growth factors I and II (IGF I, IGF II), insulin and epidermal growth factor (EGF) induce a 1.5- to 2-fold increase of mannose 6-phosphate binding sites at the cell surface of human skin fibroblasts. The increase is completed within 10-15 min, is dose and temperature dependent, reversible and transient even in the presence of the effectors. It is due to a redistribution of mannose 6-phosphate/IGF II receptors from internal membranes to the cell surface, while the affinity of the receptors is not affected. Combinations of mannose 6-phosphate with IGF I, IGF II or EGF stimulate the redistribution of the receptor to the cell surface in an additive manner, while combinations of the growth factors result in a non-additive stimulation of redistribution. The redistribution is not dependent on extracellular calcium and appears also to be independent of changes of free intracellular calcium. Pre-treatment of fibroblasts with cholera toxin or pertussis toxin increases the number of cell surface receptors 2- and 1.5-fold, respectively. Neither of the toxins affects the redistribution of mannose 6-phosphate/IGF II receptors induced by the growth factors, while both toxins abolish the receptor redistribution induced by mannose 6phosphate. These results suggest a multiple regulation of the cell surface expression of mannose 6-phosphate/IGF II receptors by $G_{s^{-}}$and $G_{i}$-like proteins sensitive to cholera toxin and pertussis toxin and by stimulation of mannose 6-phosphate/IGF II, IGF I and EGF receptors. Binding of mannose 6-phosphate/IGF II receptors with mannose 6-phosphate triggers receptor redistribution via a signal transduction pathway sensitive to cholera and pertussis toxin, while binding with IGF II triggers receptor redistribution by a mechanism resistant to these toxins.

Key words: M6P/IGF II receptor/IGF I/IGF II/EGF/ mannose 6-phosphate/expression/cell surface

\section{Introduction}

The mannose 6-phosphate/insulin like growth factor II (M6P/IGF II) receptor is a multifunctional receptor binding two structurally unrelated families of ligands (Morgan et al., 1987; Roth, 1988). The M6P-containing ligands, such as lysosomal enzymes and IGF II bind to different sites of the receptor and a single receptor can bind the two types of ligands simultaneously (Roth et al., 1987; Kiess et al., 1988;
MacDonald et al., 1988; Tong et al., 1988; Waheed et al., 1988). The role of the M6P/IGF II receptor in targeting of newly synthesized lysosomal enzymes to lysosomes and endocytosis of lysosomal enzymes has been established (von Figura and Hasilik, 1986). The lysosomal enzymes bind to the M6P/IGF II receptor via M6P residues in their oligosaccharide chains. IGF II binding to M6P/IGF II receptors has been shown to stimulate DNA-synthesis and cell proliferation, glycogen synthesis and $\mathrm{Na}^{+} / \mathrm{H}^{+}$exchange (Mellas et al., 1986; Nishimoto et al., 1987; Sessions et al., 1987; Hari et al., 1987).

About $10-20 \%$ of the M6P/IGF II receptors are expressed at the cell surface of fibroblasts (Fischer et al., 1980; Braulke et al., 1987). The surface receptors are in equilibrium with receptors in internal membranes and cycling of the receptors between the cell surface and internal membranes is independent of occupation with M6P-containing ligands (Braulke et al., 1987) or IGF II (Oka and Czech, 1986). The expression of the M6P/IGF II receptors at the cell surface can be stimulated by insulin (Oka et al., 1984; Wardzala et al., 1984) and growth hormone (Bryson and Baxter, 1987). Insulin induces a redistribution of receptors from internal membranes to the cell surface, which is associated with a decreased phosphorylation of the receptor in the plasma membrane (Covera et al., 1988a).

In the present study we report on the modulation of the expression of M6P/IGF II receptors at the cell surface by M6P, growth factors and toxins that modify G-proteins.

\section{Results}

\section{Stimulation of M6P-binding by M6P, insulin like} growth factors, insulin and epidermal growth factor For measuring the M6P binding sites pentamannose 6-phosphate substituted [ ${ }^{125}$ I]bovine serum albumin (PMP BSA) was utilized. This neoglycoprotein binds with high affinity $\left(K_{\mathrm{D}} \cong 5 \times 10^{-10} \mathrm{M}\right)$ to M6P specific receptors (Braulke et al., 1987). Prior to the binding the cells were chilled to $0^{\circ} \mathrm{C}$ and washed with $2 \mathrm{mM}$ M6P to remove endogenous ligands, which occupy about $20-30 \%$ of the cell surface receptors. The cells were then incubated for $4 \mathrm{~h}$ at $0^{\circ} \mathrm{C}$ with the iodinated ligand. [ $\left.{ }^{125} \mathrm{I}\right] \mathrm{PMP}-\mathrm{BSA}$ bound to the cell surface was released by incubation with $2 \mathrm{mM}$ M6P. The radioactivity released by M6P represented $80-90 \%$ of the total cell associated radioactivity. In the presence of $2 \mathrm{mM}$ M6P binding of [ $\left.{ }^{125} \mathrm{I}\right] \mathrm{PMP}-\mathrm{BSA}$ was inhibited by more than $85 \%$. For convenience the PMPBSA binding sites will be referred to as M6P binding sites.

Treatment of the fibroblasts for $10 \mathrm{~min}$ with $5 \mathrm{mM}$ M6P or a mixture of $10^{-8} \mathrm{M}$ IGF I and $10^{-8} \mathrm{M}$ IGF II (preparation 1932) increased the M6P binding sites to 140 and $190 \%$ of the controls (Table I). The stimulation of PMP-BSA binding in parallel dishes rarely varied by more than $10 \%$ while a considerable variability was noted between different experiments carried out over a period of 10 months 
Table I. Effect of M6P and growth factors on binding of [125I]PMP-BSA

\begin{tabular}{ll}
\hline Pre-treatment $^{\mathrm{a}}$ & $\begin{array}{l}\text { Bound } \\
{\left[\begin{array}{l}\left.{ }^{25} \mathrm{I}\right] \mathrm{PMP}-\mathrm{BSA} \\
(\% \text { of control })\end{array}\right.}\end{array}$ \\
\hline M6P $(5 \mathrm{mM})$ & $140 \pm 25(n=43)$ \\
IGF I/IGF II $\left(10^{-8} \mathrm{M}\right)$ (preparation 1932) & $190 \pm 48(n=22)$ \\
IGF I $\left(10^{-8} \mathrm{M}\right)$ & $181 \pm 35(n=10)$ \\
IGF II $\left(10^{-8} \mathrm{M}\right)$ & $143 \pm 36(n=11)$ \\
rIGF I $\left(10^{-8} \mathrm{M}\right)$ & $228 \pm 87(n=27)$ \\
rIGF II $\left(10^{-8} \mathrm{M}\right)$ & $156 \pm 47(n=25)$ \\
EGF $\left(10^{-8} \mathrm{M}\right)$ & $197 \pm 43(n=30)$ \\
Insulin $\left(10^{-7} \mathrm{M}\right)$ & 120 \\
Insulin $\left(10^{-6} \mathrm{M}\right)$ & 197 \\
Fibroblasts growth factor $\left(10^{-8} \mathrm{M}\right)$ & 89 \\
Granulocyte/macrophage colony stimulating & 92 \\
$\quad$ factor $(10 \mu \mathrm{g} / \mathrm{ml})$ &
\end{tabular}

${ }^{\mathrm{a}}$ Fibroblasts were stimulated with M6P or growth factors for $10 \mathrm{~min}$ at $37^{\circ} \mathrm{C}$ except for $10^{-6} \mathrm{M}$ insulin, which was applied for $1 \mathrm{~h}$, controls bound $0.155 \pm 0.066 \mathrm{ng} / \mathrm{mg}$ cell protein $(n=37)$.

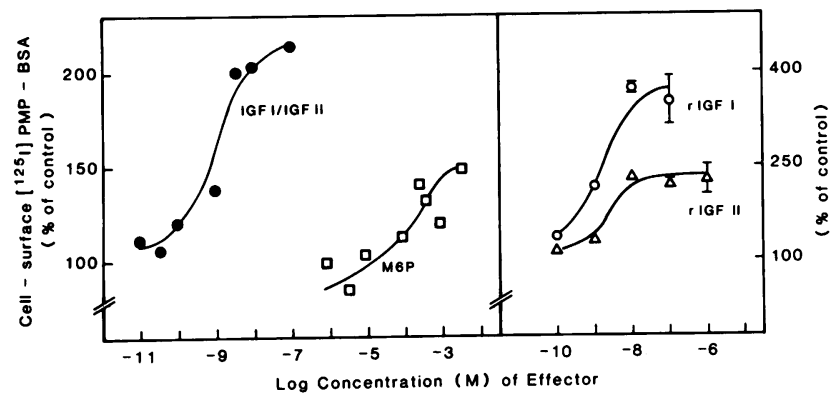

Fig. 1. Concentration dependent stimulation of $\left[{ }^{125} \mathrm{I}\right] \mathrm{PMP}-\mathrm{BSA}$ binding by M6P, a mixture of IGF I and IGF II (preparation 1932), rIGF I and rIGF II. For the experiment with rIGF I and rIGF II the range of duplicates is given where it exceeds the size of the symbols.

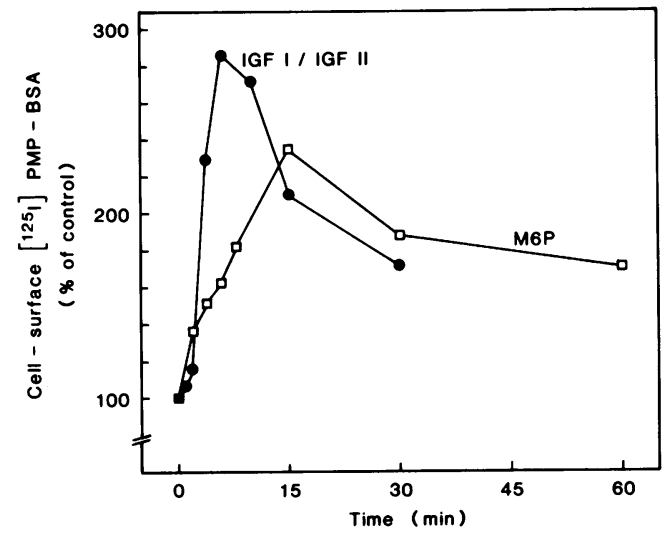

Fig. 2. Time course of the effect of $10^{-8} \mathrm{M}$ IGF I/IGF II (preparation 1932) and $5 \mathrm{mM} \mathrm{M} 6 \mathrm{P}$ to increase the cell surface binding of [ ${ }^{125}$ I]PMP-BSA.

(cf. Table I with Figures 1 and 2). The effect of M6P and IGF I/IGF II was dose-, time- and temperature-dependent. Half maximal stimulation was observed at $10^{-4} \mathrm{M}$ M6P and $10^{-9} \mathrm{M}$ IGF I/IGF II (Figure 1). A bell-shaped curve was observed for the time dependence with maximal stimulation after treatment for 15 and 8 min with M6P and IGF I/IGF II, respectively (Figure 2). After withdrawal of
Table II. Effect of phosphorylated carbohydrates on binding of PMP-BSA

\begin{tabular}{lc}
\hline Pre-treatment & $\begin{array}{l}\text { Bound }\left[{ }^{125} \text { I]PMP-BSA }\right. \\
\text { (\% of control) }\end{array}$ \\
\hline M6P & 159 \\
Fructose 1-phosphate & 143 \\
Glucose 1-phosphate & 99 \\
Glucose 6-phosphate & 116 \\
Pentamannose 6-phosphate (PMP) & 139 \\
\hline
\end{tabular}

Table III. Inhibition of $\left[{ }^{125}\right.$ I]PMP-BSA binding by anti-M6P/IGF II receptor antibodies

\begin{tabular}{llc}
\hline Pre-incubation a & Antibody & $\begin{array}{l}\text { Bound [ } \\
\text { (\% of control) }\end{array}$ \\
\hline- & pre-immune IgG & 100 \\
- & anti-M6P/IGF II receptor IgG & 10 \\
rIGF I & pre-immune IgG & 192 \\
rIGF I & anti-M6P/IGF II receptor IgG & 10 \\
\hline
\end{tabular}

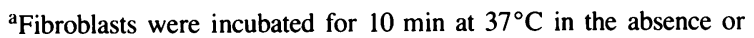
presence of ${ }^{-8} \mathrm{M}$ rIGF I. Cells were then incubated for $90 \mathrm{~min}$ at $0^{\circ} \mathrm{C}$ in MEM/7.5\% FCS containing $1.5 \mathrm{mg} / \mathrm{ml}$ of pre-immune or anti-M6P/IGF II receptor IgG. After washing with ice-cold Hanks balanced salt solution the cells were incubated for $4 \mathrm{~h}$ at $0^{\circ} \mathrm{C}$ in $\mathrm{MEM} / 7.5 \%$ FCS containing $50 \mathrm{pM}\left[{ }^{125} \mathrm{I}\right] \mathrm{PMP}-\mathrm{BSA}$.

M6P or IGF I/IGF II the number of M6P binding sites at the cell surface returned to control levels with a $t_{1 / 2}$ of 29 and $48 \mathrm{~min}$, respectively (not shown). At $\leq 16^{\circ} \mathrm{C} \mathrm{M} 6 \mathrm{P}$ and IGF I/IGF II did not stimulate the binding of PMP-BSA, while at $23^{\circ} \mathrm{C}$ an intermediate stimulation was observed (not shown).

Fructose 1-phosphate and pentamannose 6-phosphate, but not glucose 1- or glucose 6-phosphate, could mimic the M6P effect (Table II). Fructose 1-phosphate and pentamannose phosphate are known to bind to M6P-specific receptors (Kaplan et al., 1977; Waheed et al., 1988). Thus, M6P is likely to induce the increase in cell surface M6P binding sites through its interaction with M6P receptors.

When IGF I and IGF II purified from human serum were used at $10^{-8} \mathrm{M}$ concentration, IGF I was more effective than IGF II in stimulating the M6P binding (Table I). The similar difference was observed for recombinant (r) IGF I and IGF II. Dose-dependent stimulation with rIGF I and rIGF II showed that rIGF I was 1.6 -fold more potent in increasing M6P binding sites, while similar concentrations of rIGF I and rIGF II $\left(\sim 3 \times 10^{-9} \mathrm{M}\right)$ were required to obtain half maximal stimulation of binding (Figure 1). In a separate experiment, in which cells were incubated at $0^{\circ} \mathrm{C}$ with $10^{-8} \mathrm{M}$ rIGF II and then with [ $\left.{ }^{125} \mathrm{I}\right] \mathrm{PMP}-\mathrm{BSA}$, we could show that occupation of the IGF II binding site neither increased nor decreased binding of PMP-BSA.

Incubation of fibroblasts for $10 \mathrm{~min}$ with $10^{-8} \mathrm{M}$ epidermal growth factor (EGF) increased the M6P binding 2 -fold (Table I). Fibroblasts growth factor $\left(10^{-8} \mathrm{M}\right)$ and granulocyte/macrophage colony stimulating factor $(10 \mu \mathrm{g} /$ $\mathrm{ml})$ had no effect on M6P binding. Treatment with high concentrations of insulin $\left(10^{-6} \mathrm{M}\right)$ for $1 \mathrm{~h}$ stimulated M6P binding about 2-fold (Table I). Lower concentrations of insulin or shorter treatments had little or no effect on M6P binding. 
Table IV. $K_{\mathrm{D}}$ values and binding sites for PMP-BSA and binding sites for M6P/IGF II receptor antibodies in fibroblasts stimulated with M6P or growth factors

\begin{tabular}{lllll}
\hline \multicolumn{2}{l}{ Pre-treatment $^{\mathrm{a}}$} & $K_{\mathrm{D}}(\mathrm{pM})$ & M6P binding sites per cell & Bound M6P/IGF II receptor antibodies per cell $\left(\times 10^{-5} \mathrm{M}\right)$ \\
\hline$-\quad(n=12)$ & $51 \pm 14$ & $3314 \pm 1202$ & $1.10 \pm 0.37$ \\
M6P & $(n=3)$ & $52 \pm 15$ & $6098 \pm 2440$ & $1.57 \pm 0.41$ \\
IGF I & 67 & 15308 & - \\
IGF II & 36 & 4500 & - \\
rIGF I & 32 & 5113 & $2.74 \pm 0.79$ \\
rIGF II & 36 & 4192 & $2.34 \pm 0.47$ \\
EGF & $(n=3)$ & $63 \pm 23$ & $7238 \pm 2609$ & $2.10 \pm 0.56$ \\
\hline
\end{tabular}

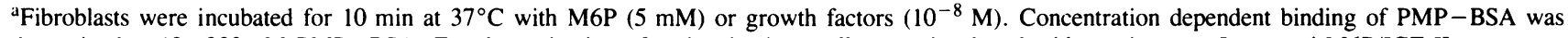
determined at 12-200 pM PMP-BSA. For determination of antigenic sites, cells were incubated with pre-immune Ig or anti-M6P/IGF II receptor Ig, followed by incubation with [ $\left.{ }^{125} \mathrm{I}\right]$ protein A. For calculation of bound $\mathrm{Ig}$ a stoichiometry of $1: 1$ was assumed for surface bound Ig and $\left[{ }^{125} \mathrm{I}\right]$ protein $\mathrm{A}$. The values are the mean of two independent experiments and were corrected for $\left[{ }^{125} \mathrm{I}\right]$ protein $\mathrm{A}$ bound to cells incubated with preimmune Ig $\left(0.68 \times 10^{5}\right.$ per cell).

\begin{tabular}{llll}
\hline \multicolumn{2}{l}{ Table V. Effect of combinations of M6P and growth factors on the binding of $\left[{ }^{125}\right.$ I]PMP-BSA } \\
\hline Effector 1 & $\begin{array}{l}\text { Effector } 2 \\
\text { Bound [ }{ }^{125} \text { I]PMP-BSA }\end{array}$ & of control) \\
\hline M6P $(143 \pm 22)$ & + rIGF I $(180 \pm 38)$ & $256 \pm 92$ & Additive \\
& + rIGF II $(140 \pm 68)$ & $199 \pm 68$ & Additive \\
& + EGF $(207 \pm 56)$ & $264 \pm 78$ & Additive \\
rIGF I $(180 \pm 38)$ & + rIGF II $(140 \pm 33)$ & $172 \pm 35$ & Non-additive \\
& + EGF $(207 \pm 56)$ & $190 \pm 55$ & Non-additive \\
rIGF II $(140 \pm 33)$ & + EGF $(207 \pm 56)$ & $212 \pm 49$ & Non-additive \\
\hline
\end{tabular}

The values for stimulation with M6P $(5 \mathrm{mM})$ or a single growth factor $\left(10^{-8} \mathrm{M}\right)$ are given in parentheses. The values represent the mean and variation of five independent experiments.

\section{Stimulation of M6P binding is due to a redistribution of M6P/IGF II receptors}

At the surface of fibroblasts two M6P-receptors are expressed, the larger M6P/IGF II receptor with an apparent size of 270000 and the smaller $M_{r} 46000$ receptor. When fibroblasts were incubated with antibodies blocking the M6P binding site of the M6P/IGF II receptor and $M_{r} 46000$ receptors, respectively, only the antibodies against the M6P/IGF II receptor inhibited the binding of PMP-BSA in control and IGF I stimulated fibroblasts (shown for antibodies against the M6P/IGF II receptor in Table III). It had been shown earlier that M6P binding sites at the cell surface of human skin fibroblasts are represented only by the M6P/IGF II receptor, in spite of the expression of the $M_{r} 46000$ receptors at the cell surface (Stein et al., 1987).

The increase in M6P binding could result from an increased affinity and/or an increased number of cell surface M6P/IGF II receptors. To distinguish between these possibilities, fibroblasts stimulated with M6P or growth factors were analysed for dose-dependent binding of PMP-BSA. None of the effectors changed the affinity for PMP-BSA, while the number of M6P binding sites per cell was increased by M6P, IGF I, IGF II and EGF (Table IV). Furthermore, the addition of $0.5 \mathrm{mM}$ cycloheximide (which inhibited protein synthesis by more than $95 \%$ ) 30 min prior to and during the stimulation did not affect the M6P, IGF I/IGF II and EGF induced increase in M6P binding. These results indicate that the increase in $\mathrm{M} 6 \mathrm{P}$ binding site results from a translocation of pre-existing M6P/IGF II receptors from internal membranes to the cell surface. This assumption was supported by the observation that binding of anti-M6P/
IGF II receptor antibodies and subsequent binding of $\left[{ }^{125} \mathrm{I}\right]$ protein $\mathrm{A}$ at the cell surface of fibroblasts was increased 1.5- to 2.7-fold after treatment with M6P (5 mM) or growth factors $\left(10^{-8} \mathrm{M}\right)$ (Table IV).

\section{Combinations of M6P and growth factors have additive effects on receptor redistribution}

Combinations of M6P with either rIGF I, rIGF II or EGF stimulated the receptor redistribution in an additive manner, while non-additive effects were observed for combinations of rIGF I with rIGF II or EGF, and of rIGF II with EGF (Table V). These observations indicate that M6P and the growth factors stimulate the redistribution of M6P/IGF II receptors by independent mechanisms. The non-additive stimulation by combinations of growth factors suggests that the mechanisms by which growth factors stimulate the receptor redistribution share common elements.

\section{The stimulation of receptor redistribution does not involve changes in free intracellular calcium}

The rapid redistribution of M6P/IGF II receptors suggests that the redistribution and the binding of M6P and growth factors are linked to second messengers. To monitor changes in free intracellular calcium $\left(\left[\mathrm{Ca}^{2+}\right]_{\mathrm{i}}\right)$ associated with redistribution of receptors, fibroblasts were loaded with the fluorescent calcium chelator fura-2-AM prior to stimulation with M6P or growth factors. The basal level of $\left[\mathrm{Ca}^{2+}\right]_{\mathrm{i}}$ in single cells varied between $\leq 0.01$ and 0.2 (mean 0.03 ) $\mu \mathrm{M}$. Stimulation with $5 \mathrm{mM}$ M6P. $10^{-8} \mathrm{M}$ IGF I or $10^{-8} \mathrm{M}$ IGF II had no effect on $\left[\mathrm{Ca}^{2+}\right]_{i}$, while $10^{-8} \mathrm{M}$ EGF in approximately half of the cells studies induced a rise of 
$\left[\mathrm{Ca}^{2+}\right]_{\mathrm{i}}$ of $0.74(0.4-2.27) \mu \mathrm{M}$ after a lag period of $35-$ $40 \mathrm{~s}$ (not shown).

The redistribution of receptors induced by M6P, a mixture of IGF I and IGF II, or EGF, was not affected by incubating and stimulating the cells in a calcium-free medium supplemented with $10^{-8} \mathrm{M}$ EGTA. Furthermore, addition of $1 \mathrm{mM} \mathrm{Co}^{2+}$ to the medium did not inhibit the effectorinduced receptor redistribution (Table VI). These observations indicate that the M6P and growth factor induced redistribution of M6P/IGF II receptors is independent of extracellular calcium.

To examine whether the EGF induced receptor redistribution depends on the increase of $\left[\mathrm{Ca}^{2+}\right]_{\mathrm{i}}$, fibroblasts were loaded with the permeable calcium chelator BABTA. When accumulated intracellularly, BABTA obliterates changes of $\left[\mathrm{Ca}^{2+}\right]_{\mathrm{i}}$ as a consequence of calcium release from intracellular stores (Gelfand et al., 1987). EGF, $10^{-8} \mathrm{M}$, led to a similar increase in M6P binding sites in controls and BABTA loaded fibroblasts (not shown). This result suggests that the EGF induced redistribution of M6P/IGF II receptors is independent of the EGF induced rise of $\left[\mathrm{Ca}^{2+}\right]_{\mathrm{i}}$.

\section{G-protein modulated expression of M6P/IGF II receptors at the cell surface}

Fibroblasts were treated for $17 \mathrm{~h}$ with cholera toxin $(1 \mu \mathrm{g} /$ $\mathrm{ml})$ or pertussis toxin $(0.1 \mu \mathrm{g} / \mathrm{ml})$. This treatment resulted in an increase of M6P binding to 195 and $144 \%$ of controls, respectively (Table VII). The increase in M6P binding was due to an increased number of M6P/IGF II receptors (examined for cholera toxin only, $K_{\mathrm{D}}=50 \mathrm{pM} ; 7500$ PMP-BSA binding sites per cell). These results suggest a control of cell surface expression of M6P/IGF II receptors by $\mathrm{G}_{\mathrm{s}}$ - and $\mathrm{G}_{\mathrm{i}}$-like proteins sensitive to cholera toxin and pertussis toxin, respectively (Neer and Clapham, 1988). Pre-incubation of fibroblast with cholera toxin and pertussis toxin did not prevent the redistribution of M6P/IGF II receptors induced by rIGF I, rIGF II and EGF (Table VIII). However, the effect of M6P on receptor redistribution was abolished or greatly reduced by pre-incubation with pertussis toxin or cholera toxin (Table VIII).

\section{Discussion}

Control of cell surface receptor expression by cAMP M6P/IGF II receptors recycle constitutively between intracellular membranes and the plasma membrane. Under steady-state conditions $10-20 \%$ of the receptors are expressed at the cell surface of human skin fibroblasts (Fischer et al., 1980; Braulke et al., 1987). Data presented in this study provide evidence that the steady-state distribution of the M6P/IGF II receptor is controlled by G-proteindependent mechanisms. The cell surface concentration of M6P/IGF II receptors increases after treatment with cholera toxin and pertussis toxin. Cholera toxin is thought to activate permanently $\mathrm{G}_{\mathrm{s}}$-like proteins and pertussis toxin to inactivate $\mathrm{G}_{\mathrm{i}}$-like proteins through toxin catalysed ADPribosylation of the respective G-proteins (Gilman, 1987). Since $G_{s}$-like proteins stimulate and $G_{i}$-like proteins can inhibit adenylyl cyclase, an effect common to both toxins could be the increase of intracellular cAMP. Further evidence for the role of cAMP in the control of M6P/ IGF II receptor distribution comes from preliminary observations (T.Braulke, unpublished results) that forskolin
Table VI. Effect of M6P and growth factors on the binding of ${ }^{125}$ I]PMP-BSA in the absence of extracellular $\mathrm{Ca}^{2+}$ or presence of $\mathrm{Co}^{2+}$

\begin{tabular}{llll}
\hline & \multicolumn{3}{l}{ Bound $\left[{ }^{125}\right.$ I]PMP-BSA (\% of control) } \\
\hline & M6P & IGF I/IGF II & EGF \\
\hline EGTA & 168 & 209 & 208 \\
$\mathrm{Co}^{2+}$ & 139 & 148 & 175 \\
\hline
\end{tabular}

Fibroblasts were incubated for $1 \mathrm{~h}$ at $37^{\circ} \mathrm{C}$ in $\mathrm{Ca}^{2+}$ free medium, supplemented with $10^{-8} \mathrm{M}$ EGTA and then stimulated for $10 \mathrm{~min}$ with M6P $(5 \mathrm{mM})$ or growth factors $\left(10^{-8} \mathrm{M}\right)$. Alternatively, cells were stimulated in the presence of $1 \mathrm{mM} \mathrm{Co}^{2+}$. The values are expressed as percent of controls, which were incubated with the $\mathrm{Ca}^{2+}$ free medium or medium supplemented with $1 \mathrm{mM} \mathrm{CoCl}{ }_{2}$.

Table VII Effect of cholera toxin and pertussis toxin on binding of [125I]PMP-BSA

\begin{tabular}{ll}
\hline Pre-incubation $^{\mathrm{a}}$ & Bound [ ${ }^{125}$ I]PMP-BSA (\% of control) \\
\hline Cholera toxin $(n=12)$ & $195 \pm 44$ \\
Pertussis toxin $(n=8)$ & $144 \pm 23$
\end{tabular}

${ }^{\mathrm{a}}$ Fibroblasts were incubated for $17 \mathrm{~h}$ at $37^{\circ} \mathrm{C}$ with cholera toxin $(1 \mu \mathrm{g} / \mathrm{ml})$ or pertussis toxin $(0.1 \mu \mathrm{g} / \mathrm{m})$ prior to the binding assay. Controls bound $0.101 \pm 0.06 \mathrm{ng} / \mathrm{mg}$ cell protein $(n=12)$.

Table VIII. Effects of M6P and growth factors on binding of $\left[{ }^{125}\right.$ I]PMP - BSA by fibroblasts incubated with cholera toxin or pertussis toxin

\begin{tabular}{lll}
\hline Pre-incubation $^{\mathrm{a}}$ & $\begin{array}{l}\text { Cholera toxin } \\
(1 \mu \mathrm{g} / \mathrm{ml})\end{array}$ & $\begin{array}{l}\text { Pertussis toxin } \\
(0.1 \mu \mathrm{g} / \mathrm{ml})\end{array}$ \\
\hline Stimulation & & \\
- & 260 & 150 \\
M6P & 286 & 149 \\
rIGF I & 528 & 297 \\
rIGF II & 406 & 221 \\
EGF & 455 & 317 \\
\hline
\end{tabular}

${ }^{\mathrm{a}}$ Fibroblasts were incubated for $17 \mathrm{~h}$ at $37^{\circ} \mathrm{C}$ with the toxins and then for $10 \mathrm{~min}$ with $\mathrm{M} 6 \mathrm{P}(5 \mathrm{mM})$ or growth factors $\left(10^{-8} \mathrm{M}\right)$. All values represent the mean of duplicates.

and 3-isobutyl-1-methylxanthine increase the cell surface concentration of M6P/IGF II receptors. These drugs elevate intracellular cAMP levels by stimulating adenylyl cyclase (forskolin) or inhibiting cAMP-phosphodiesterase (3isobutyl-1-methylxanthine).

\section{Stimulation of M6P/IGF II-, IGF I- and EGF-receptors} induces redistribution of M6P/IGF /I receptors

M6P, IGF I, IGF II, insulin and EGF induced in fibroblasts a redistribution of $\mathrm{M} 6 \mathrm{P} / \mathrm{IGF}$ II receptors to the cell surface. M6P is likely to induce the receptor redistribution through binding with the M6P/IGF II receptor. The concentration of $\mathrm{M} 6 \mathrm{P}$ required to achieve half maximal effect $(\cong 0.1 \mathrm{mM}$ ) and the agonistic effect of the structurally related fructose 1-phosphate are characteristic for a signalling via the M6P binding site(s) of M6P/IGF II receptors.

IGF I and IGF II may bind to either IGF I or M6P/IGF II receptors and could therefore induce the receptor distribution by binding with either type of receptor. Two observations suggest that the IGF I effect is mediated by IGF I receptors and that of IGF II by M6P/IGF II receptors. In 
general, IGF I receptors have a higher affinity for IGF I than for IGF II and M6P/IGF II receptors a higher affinity for IGF II than for IGF I (Rechler and Nissley, 1985; Maly and Lüthi, 1986). More recent analyses with synthetic and recombinant IGF I suggest that M6P/IGF II receptors may have little or no affinity for IGF I (Tally et al., 1987a; Barenton et al., 1987). Effects of IGF I and IGF II mediated by the same receptor would therefore display a different concentration dependence for the two growth factors. However, similar concentrations of rIGF I and rIGF II ( $\cong 3$ $\times 10^{-9} \mathrm{M}$ ) induced half maximal receptor redistribution. Furthermore, the extent of receptor redistribution was significantly different for IGF I and IGF II. This suggests that IGF I and IGF II induce the redistribution via different signal transduction pathways, initiated by binding of IGF I and IGF II to the IGF I and M6P/IGF II receptor, respectively.

Insulin has been shown earlier to induce a redistribution of M6P/IGF II receptors from internal membranes to the cell surface by binding with insulin receptors in rat adipocytes (Oka et al., 1984; Wardzala et al., 1984) and rat H35-hepatoma cells (Covera et al., 1988a). The insulin receptor-mediated redistribution is associated with a decrease in the overall phosphorylation of the M6P/IGF II receptor (Covera et al., 1988a). In fibroblasts no significant change in the overall phosphorylation of M6P/IGF II receptors was observed after stimulation with M6P, IGF II, IGF I and EGF (T.Braulke, unpublished results). The high concentrations of insulin that are required to induce redistribution of M6P/ IGF II receptors precludes mediation of the insulin effect in fibroblasts by insulin receptors. It is likely to depend on IGF I receptors, to which insulin binds with low affinity (Rechler and Nissley, 1985).

EGF induced a rapid increase in $\left[\mathrm{Ca}^{2+}\right]_{\mathrm{i}}$, which preceded the EGF induced receptor redistribution. Abolishing the rise in $\left[\mathrm{Ca}^{2+}\right]_{\mathrm{i}}$ by inhibiting calcium influx from extracellular sources or by chelating calcium released from intracellular storage pools did not impair the EGF induced receptor redistribution. The EGF induced redistribution of M6P/IGF II receptors is therefore likely to be unrelated to the EGF induced rise in $\left[\mathrm{Ca}^{2+}\right]_{\mathrm{i}}$.

\section{Binding of M6P and IGF || with M6P/IGF || receptors triggers different signal transducing pathways}

Pre-incubation of fibroblasts with cholera toxin or pertussis toxin severely decreased or virtually abolished the receptor redistribution induced by M6P. This suggests that binding of M6P to the M6P/IGF II receptor initiates a signal transducing pathway linked to $\mathrm{G}_{\mathrm{s}}$ - and $\mathrm{G}_{\mathrm{i}}$-like proteins. IGF II stimulated the M6P/IGF II receptor redistribution via a mechanism insensitive to cholera toxin and pertussis toxin. Moreover, the effects of M6P and IGF II on receptor redistribution were additive. These observations imply that binding of M6P/IGF II receptors with M6P or IGF II initiates the receptor redistribution via different signal transducing pathways. The M6P/IGF II receptor appears therefore to be a multifunctional protein which binds different classes of ligands at its external domain and is linked to different signal transducing systems at its cytoplasmic domain.

Little is known about the coupling of M6P/IGF II receptors to signal transducing pathways. In basolateral membranes of the renal proximal tubular cell, IGF II stimulates the formation of phosphatidylinositol 4,5-bisphosphate and di- acylglycerol (Rogers and Hammerman, 1988). In competent BALB/c 3T3 cells primed with EGF, rIGF II stimulates calcium influx via a mechanism sensitive to pertussis toxin (Nishimoto et al., 1987). Since phospholipase C mediated formation of phosphatidylinositol 4,5-bisphosphate results in increased intracellular calcium levels, both effects may result from an IGF II induced activation of phospholipase C. We were unable to demonstrate an increase of $\left[\mathrm{Ca}^{2+}\right]_{i}$ in fibroblasts stimulated with M6P or IGF II, suggestging that the M6P and/or IGF II receptor induced redistribution are not linked to a (phospholipase $\mathrm{C}$ induced) rise in intracellular calcium.

\section{Biological function of cell surface M6P/IGF II receptors}

Fairly little is known about the biological function of M6P/ IGF II receptors at the cell surface. These receptors bind and mediate internalization of M6P-containing compounds (lysosomal enzymes, uteroferrin, proliferin) and of IGF II. The biological role of these functions remains to be established. IGF II binding to its receptor has been shown to stimulate glycogen synthesis in rat hepatoma cells (Hari et al., 1987), to stimulate proliferation of K-562 cells (Tally et al., 1987b), to alkalinize cells of the proximal tubular segment from canine kidney by stimulating $\mathrm{Na}^{+} / \mathrm{H}^{+}$ exchange across the brush border membrane (Mellas et al., 1986) and to stimulate $\mathrm{Ca}^{2+}$ influx and DNA synthesis in competent BALB/c $3 \mathrm{~T} 3$ cells primed with EGF (Nishimoto et al., 1987). Preliminary experiments have shown that IGF II (as well as IGF I and EGF) stimulates in fibroblasts the uptake of PMP-BSA to a similar extent as the binding of PMP-BSA (S.Tippmer and T.Braulke, unpublished results). Growth factors may therefore stimulate both binding and internalization of the ligands of the M6P/IGF II receptor and thereby modulate M6P/IGF II receptor mediated functions. In addition to an increase of the overall concentration of M6P/IGF II receptors at the cell surface, growth factors may distinctly affect subpopulations of receptors within the plasma membrane. For rat adipocytes it was recently shown that phosphorylation of M6P/IGF II receptors in coated pits is 20-40 times higher than outside of coated pits. Insulin increases the number of M6P/IGF II receptors in the plasma membrane outside of coated pits and decreases the phosphorylation of receptors associated with coated pits (Covera et al., 1988b). Furthermore, it remains to be determined which changes in receptor distribution in internal membranes are induced by growth factors. It may be that some biological responses to the M6P and growth factor induced redistribution of M6P/IGF II receptors depend on changes of the M6P/IGF II receptors in the internal membranes rather than at the cell surface. For example, changes of the M6P/IGF II receptor concentrations in the Golgi/trans Golgi network area may affect the secretion or retention of endogenous receptor ligands (lysosomal enzymes or IGF II).

\section{Materials and methods}

\section{Growth factors and chemicals}

IGF I and IGF II purified from human serum and a mixture of IGF I and IGF II (preparation 1932) were a kind gift of Dr R.Humbel, University of Zürich. Human IGF I and IGF II produced by recombinant DNA technology were obtained from Dr K.Scheibli, Ciba-Geigy, Basel. EGF, fibroblast growth factor and granulocyte/macrophage colony stimulating 
factor were obtained from Boehringer-Mannheim. M6P (sodium salt), cholera toxin and pertussis toxin were from Sigma. Fura-2-AM and BABTA - AM were obtained from Molecular Probes (Junction City, OR, USA), insulin and recombinant protein A were from Serva. Pentamannose 6-phosphate was prepared according to Bretthauer et al. (1973), from Hansenula holstii phosphomannan, which was kindly provided by Dr M.Slodki (United States Department of Agriculture, Northern Regional Research Center, Peoria, IL, USA). PMP-BSA (bovine serum albumin) was prepared and iodinated with $\mathrm{Na}\left[{ }^{125} \mathrm{I}\right]$ to a specific activity of $350 \mathrm{mCi} / \mathrm{mg}$ with the aid of iodogen (Pierce Chemical Co., Rockford, IL, USA) as described (Braulke et al., 1987). Protein A was iodinated with iodogen to a specific activity of $1 \mathrm{mCi} / \mathrm{mg}$.

\section{Cell culture and stimulation protocol}

Human skin fibroblasts were grown in 35-mm dishes in minimal essential medium (MEM) with $7.5 \%$ fetal calf serum to confluency. The cells were washed, incubated at $37^{\circ} \mathrm{C}$ for $1 \mathrm{~h}$ in MEM containing $0.1 \% \mathrm{BSA}$ and then stimulated with sugar phosphates or growth factors in the albumin-substituted medium. In experiments with cholera toxin and pertussis toxin, the cells were incubated for $16 \mathrm{~h}$ with MEM containing $7.5 \%$ fetal calf serum and the toxins and then for $1 \mathrm{~h}$ with albumin-substituted MEM containing the toxins.

\section{Binding and uptake of [ ${ }^{125}$ I]PMP - BSA}

After stimulation at $37^{\circ} \mathrm{C}$ with the growth factors or M6P, the cells were washed twice for $10 \mathrm{~min}$ with $1 \mathrm{ml}$ of ice-cold Hank's buffered salt solution containing $2 \mathrm{mM}$ M6P. The cells were then incubated for $4 \mathrm{~h}$ at $0^{\circ} \mathrm{C}$ with $0.6 \mathrm{ml}$ of MEM containing 7.5\% fetal calf serum, $20 \mathrm{mM}$ Hepes, $\mathrm{pH} 7.2$, and $2 \mathrm{ng}$ of [ $\left.{ }^{125} \mathrm{I}\right] \mathrm{PMP}-\mathrm{BSA}$. Bound [ $\left.{ }^{125} \mathrm{I}\right] \mathrm{PMP}-\mathrm{BSA}$ was displaced by two washes with M6P-supplemented salt solution as above. The cells were solubilized in $1 \mathrm{~N} \mathrm{NaOH}$. Radioactivity was determined in the M6P washes and the solubilized cells and referred to cell protein (Lowry et al.. 1951). Concentration dependent binding of PMP-BSA was analysed at 12-200 pM PMP-BSA.

Binding of anti-M6P/IGF || receptor antibodies, $\left.\right|^{125}$ /]protein A Fibroblasts grown in 24-well plates were incubated for $2 \mathrm{~h}$ at $0^{\circ} \mathrm{C}$ with pre-immune IgG or affinity purified anti-M6P/IGF II receptor antibodies $(5 \mu \mathrm{g} / \mathrm{well})$ in $0.2 \mathrm{ml}$ of MEM, containing $7.5 \%$ fetal calf serum, $20 \mathrm{mM}$ Hepes, $\mathrm{pH}$ 7.2. After washing the cells were incubated with [ $\left.{ }^{125} \mathrm{I}\right]$ protein A (45 ng/well) for $16 \mathrm{~h}$ at $0^{\circ} \mathrm{C}$. The cells were washed and solubilized in $1 \mathrm{~N} \mathrm{NaOH}$ for determination of radioactivity and cell protein.

\section{Determination of $\left[\mathrm{Ca}^{2+}\right]_{i}$}

$\left[\mathrm{Ca}^{2+}\right]_{\mathrm{i}}$ was determined by fluorescence measurements on single cells loaded with fura-2-AM (Grynkiewicz et al., 1985; Neher, 1988). Cells were incubated for $30 \mathrm{~min}$ at room temperature in saline containing $2 \mu \mathrm{M}$ fura-2-AM, followed by incubation at $37^{\circ} \mathrm{C}$ in standard culture medium. Average autofluorescence was measured on non-loaded cells and corrected for. Autofluorescence varied considerably between cells such that absolute values of $\left[\mathrm{Ca}^{2+}\right]_{i}$ cannot be considered to be accurate. M6P $(5 \mathrm{mM})$ and growth factors $\left(10^{-8} \mathrm{M}\right)$ in MEM, $20 \mathrm{mM}$ Hepes, $\mathrm{pH} 7.2$, containing $0.1 \%$ BSA were applied locally for $20-60 \mathrm{~s}$ through a close-by pipette with an opening of $2-3 \mu \mathrm{m}$.

For loading with BABTA, cells were incubated for $30 \mathrm{~min}$ at $37^{\circ} \mathrm{C}$ in MEM containing $20 \mathrm{mM}$ Hepes, pH 7.2, 0.1\% BSA and $50 \mu \mathrm{M}$ BABTA - AM, chased for $30 \mathrm{~min}$ in the same medium without BABTA $\mathrm{AM}$ and then stimulated with EGF $\left(10^{-8} \mathrm{M}\right)$.

\section{Acknowledgements}

This study was supported by the Deutsche Forschungsmeinschaft (SFB 236) and the Fonds der Chemischen Industrie.

\section{References}

Barenton,B., Guyda,H.J., Goodyer,C.G., Polychronakos,C. and Posner,B.I. (1987) Biochem. Biophys. Res. Commun., 149, 555-561.

Braulke,T., Gartung,C., Hasilik,A. and von Figura.K. (1987) J. Cell Biol., 104, $1735-1742$.

Bretthauer, R.K., Kaczorowski,G.J. and Weise,M.J. (1973) Biochemistry, 12, $1251-1256$.

Bryson,J.M. and Baxter,R.C. (1987) J. Endocrinol., 113, 27-35.

Covera,S., Roach,P.J., DePaoli-Roach,A.A. and Czech,M.P. (1988a) J.

Biol. Chem., 263, 3116-3122.
Covera,S., Folander,K., Clairmont,K.B. and Czech,M.P. (1988b) Proc. Natl. Acad. Sci. USA, 85, 7567-7571.

Fischer,H.D., Gonzalez-Noriega,A. and Sly,W.S. (1980) J. Biol. Chem., 255, 5069-5074.

Gelfand,E.W., Mills, G.B., Cheung,R.K., Lee,J.W.W. and Grinstein,S. (1987) Immunol. Rev., 95, 59-87.

Gilman,A.G. (1987) Annu. Rev. Biochem., 56, 615-650.

Grynkiewicz,G., Poenie,M. and Tsien,R.Y. (1985) J. Biol. Chem., 260. $3440-3450$.

Hari,J., Pierce,S.B., Morgan,D.O., Sara,V., Smith,M.C. and Roth,R.A. (1987) EMBO J., 6, 3367-3371.

Kaplan,A., Achord,D.T. and Sly,W.S. (1977) Proc. Natl. Acad. Sci. USA, 74, 2026-2030.

Kiess,W., Blickenstaff,G.D., Sklar,M.M., Thomas,C.L., Nissley,S.P. and Sahagian,G.G. (1988) J. Biol. Chem., 263, 9339-9344.

Lowry,O.H., Rosebrough,N.J., Farr,A.L. and Randall,R.J. (1951) J. Biol. Chem., 193, 265-275.

MacDonald,R.G., Pfeffer.S.R., Coussens,L., Tepper,M.A., Brocklebank, C.M., Mole,J.E., Anderson,J.K., Chen,E., Czech,M.P. and Ullrich,A. (1988) Science, 239, 1134-1137.

Maly,P. and Lüthi,C. (1986) Biochem. Biophys. Res. Commun., 138, $1257-1262$.

Mellas,J., Gavin,J.R. and Hammerman,M.R. (1986) J. Biol. Chem., 261 . $14437-14442$.

Morgan,D.O., Edman,J.C., Standring,D.N., Fried,V.A., Smith,M.C., Roth,R.A. and Rutter,W.J. (1987) Nature, 329, 301-307.

Neer.E.J. and Clapham.D.E. (1988) Nature, 333, 129-134.

Neher,E. (1988) J. Physiol., 395, 193-214.

Nishimoto,I., Hata,Y., Ogata,E. and Kojima,I. (1987) J. Biol. Chem., 262. $12120-12126$.

Oka,Y. and Czech,M.P. (1986) J. Biol. Chem., 261, 9090-9093.

Oka,Y., Mottola,C., Oppenheimer,C.L. and Czech,M.P. (1984) Proc. Natl. Acad. Sci. USA, 81, 4028-4032.

Rechler,M.M. and Nissley,S.P. (1985) Annu. Rev. Physiol., 47, 425-442.

Rogers,S.A. and Hammerman,M.R. (1988) Proc. Natl. Acad. Sci. USA, 85, 4037-4041.

Roth,R.A. (1988) Science, 239, 1269-1271.

Roth,R.A., Stover,C., Hari,J., Morgan,D.O., Smith,M.C., Sara,V. and Fried,V.A. (1987) Biochem. Biophys. Res. Commun., 149, 600-606.

Sessions,C.M., Emler,C.A. and Schalch,D.S. (1987) Endocrinology, 120. $2108-2116$.

Stein,M., Zijderhand-Bleekemolen.J.E., Geuze.H. . Hasilik,A. and von Figura,K. (1987) EMBO J., 6, 2677-2681.

Tally,M., Enberg,G., Lie,C.H. and Hall,K. (1987a) Biochem. Biophys. Res. Commun., 147, 1206-1212.

Tally,M., Li,C.H. and Hall,K. (1987b) Biochem. Biophys. Res. Commun., 148, $811-816$

Tong,P.Y., Tollefsen,S.E. and Kornfeld,S. (1988) J. Biol. Chem., 263. $2585-2588$.

von Figura,K. and Hasilik,A. (1986) Annu. Rev: Biochem., 55, 167-193.

Waheed,A., Braulke,T., Junghans,U. and von Figura,K. (1988) Biochem. Biophys. Res. Commun., 152, 1248-1254.

Wardzala,L.J., Simpson,I.A., Rechler,M.M. and Cushman,S.W. (1984) J. Biol. Chem., 259, 8378-8383.

Received on September 29, 1988; revised on December 14, 1988 